The Spectrum of

\title{
NREL Scientists Spurred the Success of Multijunction Solar Cells
}

Before 1984, many scientists believed that high-quality gallium indium phosphide (GalnP) alloys could not be grown for use as semiconductors because the alloys would separate. One researcher at the Solar Energy Research Institute (SERI) thought differently. His name was Jerry Olson, and his innovative thinking changed solar history. Olson identified a material combination that allowed the multijunction cell to flourish. It is now the workhorse that powers satellites and the catalyst for renewed interest in concentrator photovoltaic (CPV) products.

In the early 1980s, Olson was a scientist at SERI, the predecessor of the National Renewable Energy Laboratory (NREL). At the time, solar researchers were looking for the ideal combination of semiconductors that could be layered atop each other to produce a cell that could most efficiently convert sunlight to energy. The materials' bandgaps would need to align to work efficiently together. A bandgap is the energy difference between certain energy bands at the atomic level, and it dictates which wavelengths of light a solar cell can convert into electricity.

Olson thought the focus should change to finding materials with chemical and structural compatibility - materials that had a bandgap combination that would give a high, but not necessarily the highest, theoretical efficiency.

After studying the third and fifth columns of the Periodic Table (III-V elements), Olson reasoned that GalnP and gallium arsenide (GaAs) would have the sought-after compatibility. Among other advantages, the two semiconductors are well matched chemically and have

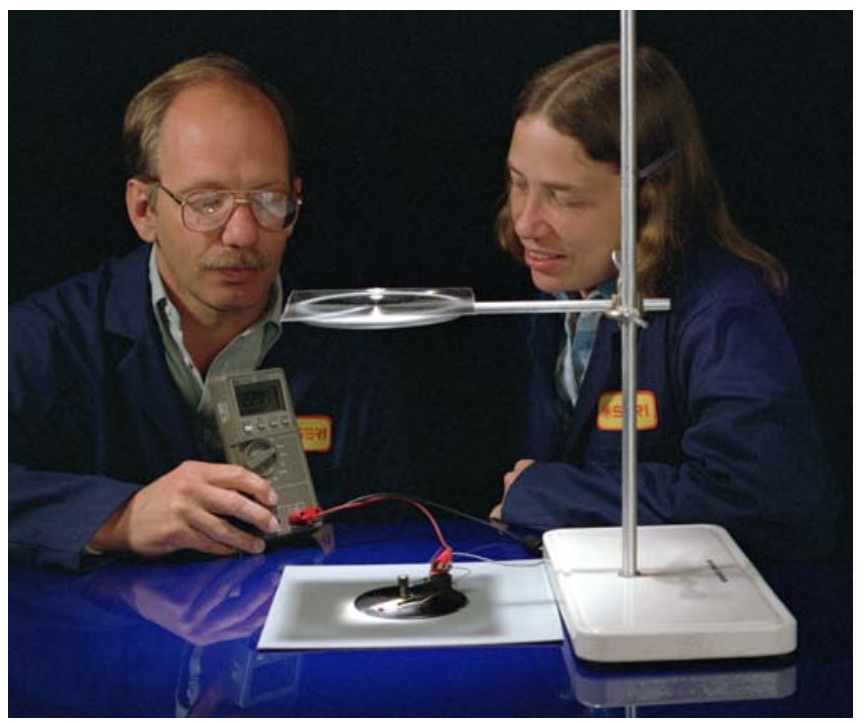

This photo, circa 1994, shows Jerry Olson and Sarah Kurtz testing the voltage output of their award-winning gallium indium phosphide/gallium arsenide tandem solar cell, which had achieved record efficiencies, converting more than $30 \%$ of incident sunlight into electricity. Photo by Warren Gretz, NREL/PIX 02002
Clean Energy Innovation

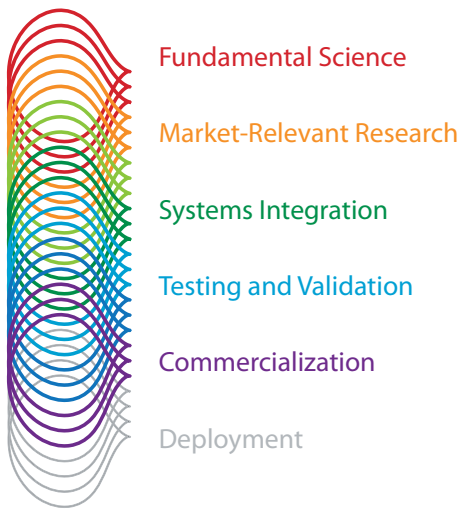

Through deep technical expertise and an unmatched breadth of capabilities, NREL leads an integrated approach across the spectrum of renewable energy innovation. From scientific discovery to accelerating market deployment, NREL works in partnership with private industry to drive the transformation of our nation's energy systems.

This case study illustrates NREL's innovations in Fundamental Science through Commercialization
NREL is a national laboratory of the U.S. Department of Energy, Office of Energy Efficiency and Renewable Energy, operated by the Alliance for Sustainable Energy, LLC. 
the same lattice constant, an indicator of how their crystals fit together at the atomic and molecular levels.

Many in the research community predicted failure because of the phase-separation issue. Even so, the U.S. Department of Energy funded the effort in 1984. Olson then worked to combine a top layer of GalnP, with a bandgap of 1.9 electron volts (eV), and a bottom layer of GaAs, with a band gap of $1.4 \mathrm{eV}$. He applied for a patent for this "tandem-junction" solar cell the same year.

In 1986, a young scientist named Sarah Kurtz joined Olson's team to help further advance the cell. Kurtz specialized in measuring material and device properties. "When I joined Jerry's team, I heard it was a long-term project and I should expect that we wouldn't see the pay-off for 30 years," she says. Indeed, the first cells produced at the lab that year were less than $10 \%$ efficient.

Olson wasn't dissuaded, Kurtz says. "The brilliance of his achievement was partly that he was willing to set that aside, even in the face of people telling him that his approach would never work."

Olson thought the efficiency could be improved by purifying the indium, which was sure to happen if the solar industry could see the advantage. He and his team eventually showed that a top cell of GalnP and a bottom cell of GaAs could capture and convert photons more efficiently into electricity than other materials.

Subsequently, all major research entities working on III-V solar cells adopted some version of the GalnP/GaAs cell. True to Olson's prediction, as knowledge and processes advanced, efficiency surged. After obtaining his patent in 1987, Olson's tandem-junction solar cell surpassed 22\% efficiency in 1988, a rapid increase over four years. The cells using GalnP surpassed 30\% in 1996. Afterward, the NREL team and scientists worldwide started adding more semiconductor junctions, and the record steadily increased.

The cell design has been modified over the years, but all current commercial architectures use GalnP as the top cell, building on Olson's tandem-junction solar cell. More than a dozen companies are now capable of growing these devices.

\section{The Impact}

Multi-junction solar cells have been chosen for most space applications since the 1990s. They are used on satellites and powered the first two Mars rovers, Spirit and Opportunity; the solar cells' durability extended the rovers' lifetimes beyond predictions. Here on earth, the recent advent of CPV, in which lenses or mirrors concentrate the sun's energy several hundred times onto super-efficient PV cells, allows an increase in the electricity generated by the same factor. A few years ago, NREL and Solar Junction, Inc. partnered to develop the multijunction SJ3 concentrator solar cell, which set a new efficiency record at 43.5\% under concentrated sunlight. Applications in utility-scale CPV are producing electricity at the rate of about 100 gigawatt-hours per year. The research that Olson led on the basic science of GalnP also aided the development of red light-emitting diodes (LEDs), used in stop lights and laser pointers.

All this technological progress was possible because about 30 years ago Jerry Olson trusted his hunch, ignored the naysayers, and invented a practical approach to a tandem-junction solar cell. That accomplishment laid the groundwork for today's multijunction solar cells, which are greater than 40\% efficient. This technology has burgeoned into a foundational device for the space industry and is positioned to be a major player in the terrestrial PV industry.

\section{NREL Scientists Recognized by Photovoltaic Industry}

Jerry Olson and Sarah Kurtz have been instrumental in clearing hurdles to ensure that the multijunction GalnP/GaAs solar cell remains the top cell for efficiency. Olson is now emeritus and Kurtz is a principal scientist and manager of the Module Reliability and Systems Engineering Group at NREL. Both scientists and their colleagues have won multiple prestigious awards for their contributions to solar cell technology.

\section{A Selection of NREL Awards for Multijunction Solar Cell Research}

1991 R\&D 100 Award for the GalnP2/GaAs dual-junction solar cell. The R\&D 100 Awards are presented by $R \& D$ Magazine to the top 100 technological innovations of the year.

2001 R\&D 100 Award for the GalnP2/GaAs/Ge triple junction solar cell

2007 Dan David Prize, a $\$ 1$ million award for "exceptional and profound contributions to the field of photovoltaic energy" (Olson and Kurtz; the prize was shared with NASA climate scientist James Hansen)

Institute of Electrical and Electronics Engineers Cherry Award for advancement of photovoltaic energy conversion (awarded to Olson in 2011 and Kurtz in 2012)

2012 R\&D 100 Award for the SJ3 Solar Cell with Solar Junction

\section{National Renewable Energy Laboratory}

15013 Denver West Parkway

Golden, CO 80401

303-275-3000 • www.nrel.gov

NREL is a national laboratory of the U.S. Department of Energy, Office of Energy Efficiency and Renewable Energy, operated by the Alliance for Sustainable Energy, LLC.

NREL/FS-6A42-53604 • September 2012

Printed with a renewable-source ink on paper containing at least $50 \%$ wastepaper, including $10 \%$ post consumer waste.

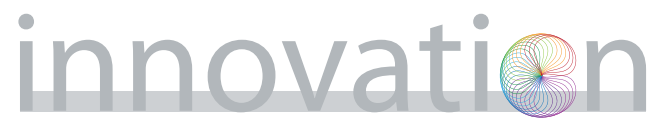

